\section{FLORA OF PROTECTED AREAS - 1 ORCHID FLORA OF PHULWARI WILDLIFE SANCTUARY, UDAIPUR DISTRICT, RAJASTHAN}

\author{
Satish Kumar Sharma \\ Range Forest Officer, Phulwari Wildlife Sanctuary, Kotra, Udaipur, \\ Rajasthan 307025, India.
}

The so-called dry state of Rajasthan has ten species of orchids in its geographical limits viz., Aerides crispum, A. multiflora, A. maculosum, Epipactis veratrifolia, Eulophia ochreata, Habenaria marginata, H. digitata, Vanda tessellata, V. testacea and Zeuxine strateumatica (Shetty \& Singh, 1991). Two more species of orchids namely, Nervilia aragoana and Habenaria longicorniculata have been recently reported from Rajasthan (Sharma, 2001, 2002).

The main concentration of orchids is present in three localities in Rajasthan, i.e., Mount Abu in Sirohi District, Phulwari Wildlife Sanctuary in Udaipur District at the southernmost end of the state near Gujarat border and Sitamata Wildlife Sanctuary in Udaipur-Chittorgarh districts. So far, only Mount Abu has been explored thoroughly and six species of orchids were reported from this hill station (Mehta, 1979; Sharma, 2002). None of the earlier literature on the flora of Rajasthan (Shetty \& Singh 1987, 1991, 1993) has any information about orchid flora of Phulwari (or Phulwari ki Nal) and Sitamata Wildlife Sanctuaries, hence to bridge the gap, a survey was conducted from 1993 to 2001 in and around Phulwari Sanctuary to list the orchids.

Phulwari is an important sanctuary that has many semievergreen small patches in the valleys. Rest of the forest cover is of deciduous type. The findings of the orchid survey is presented in Table 1.

Table 1 provides the list of six orchid species present in and around Phulwari Sanctuary. Phulwari is the second record for Nervilia aragoana from Rajasthan. The earlier record of this species being Sitamata Sanctuary only (Sharma, 2001). N. aragoana is present along the banks of rivulets under the shade of Madhuca indica. Habenaria longicorniculata was recorded near Paliyakheda Village in Jhadol Tehsil. Since similar habitat exists in Phulwari at many localities, this species might be present within the legal boundaries of this Sanctuary.
Presence of Acampe praemorsa has not been reported earlier from any part of Rajasthan (Shetty \& Singh, 1987, 1991, 1993). This is the first report of its occurrence in Phulwari Sanctuary as well as from Rajasthan State.

Acampe praemorsa was found to be abundant as an epiphyte on Madhuca indica trees between Katawali-wali-Jer and Daiya in Panarwa Range of the Sanctuary.

Orchids are safe in Phulwari Sanctuary except Vanda tessellata and Eulophia ochreata, which have some pressure due to traditional uses. Vanda tessellata is used in few ethnomedicines by the Bhils, a local tribe of the area, in treatment of ailments of their cattle. Paste of 'tubers' of Eulophia ochreata is applied by Bhils and Garasias on their bows to enhance elasticity and strength of their weapon. Certain preparations of this plant are used as an aphrodisiac by tribals.

It was observed that isolated Madhuca indica trees did not harbour any orchids or had only few. But, when this tree species was present in the form of pure patches, almost every tree possessed a number of orchids on the stem and branches except for the border trees towards western side. Taking the year as a whole, winds from south-west and west are most common, which carry the seeds of orchids towards the eastern side. Thus seeds of orchids fail to reach the trees of Mahua present on the western border of the grove making them nearly orchid-free.

Arboreal orchids were generally observed on old trees that had developed roughness in their bark. Rough bark provides suitable surface for the orchids to cling.

\section{Acknowledgements}

The author is very greateful to Sh. Rahul Bhatnagar, Dy. CWLW and Sh. P.S. Chundawat, ACF, and Sh. H.S. Solanki, RFO for facilities.

\section{References}

Mehta, M.R. (1979). Flora of Mount Abu. Ph.D. Thesis. University of Jodhpur.

Sharma. S.K. (2001). New record of Nervilia aragoana in Rajasthan. Journal of the Bombay Natural History Society 98(3): 493.

Sharma, S.K. (2002). Occurrence of Habenaria longicorniculata Grah. Family Orchidaceae in Mount Abu Wildlife Sanctuary, Rajasthan. Journal of the Bombay Natural History Society 99(1): 156.

Shetty, B.V. and V. Singh (1987). Flora of Rajasthan. Vol. I. Botanical Survey of India. Pp.1 -451.

Shetty B.V. and V. Singh (1991). Flora of Rajasthan. Vol. II. Botanical Survey of India. Pp.453-860.

Shetty B.V. and V. Singh (1993). Flora of Rajasthan. Vol. III. Botanical Survey of India. Pp. 861-1246. 
Table 1. Orchid flora of Phulwari Wildlife Sanctuary

\begin{tabular}{|c|c|c|c|}
\hline Scientific name & Local name & $\begin{array}{l}\text { Localities recorded (with status)* } \\
\text { within the Sanctuary }\end{array}$ & Outside the Sanctuary \\
\hline Aerides maculosa & Vahi-hankal & $\begin{array}{l}\text { Near Katawali-wali-Jer(A), Ambavi (A), } \\
\text { Daiya }(A) \text { (All in Daiya Forest Block) }\end{array}$ & Nala Village near Phalasia in Som-I Forest Block (A) \\
\hline Vanda tessellata & Vahi-hankal & $\begin{array}{l}\text { Near Katawali-wali-Jer(A), Ambavi (A), } \\
\text { Daiya (A) (All in Daiya Forest Block) } \\
\text { near Khanchan Forest Chowki in Phulwari } \\
\text { Forest Block (C), Bhader Bavsi in Deoli } \\
\text { Block, God-Kaoocha and Phuldariya } \\
\text { villages in Dhedmaria Block (C), Dungaria } \\
\text { Village in Deoli Block (R), between Mahad and } \\
\text { Jed in Ada Haldu Forest Block (A) }\end{array}$ & $\begin{array}{l}\text { Kamalnath RF(R), between Sarwan and Som villages }(A) \text {, } \\
\text { Amaliya in Som II Forest Block, Vanaz in VijayNagar } \\
\text { Range in Gujarat State }(C) \text {. }\end{array}$ \\
\hline Eulophia ochreata & Kukadia & Harva Forest Black near Birothi Village (R) & Jhameri Forest (Jhadol) (R) \\
\hline Habenaria longicorniculata & - & - & $\begin{array}{l}\text { Northeast of Paliyakheda village in a nullah near } \\
\text { AAP Anicut }(R)\end{array}$ \\
\hline Nervilia aragoana & - & $\begin{array}{l}\text { Near Tinduri village along the shady banks of } \\
\text { rivulets on Nalwa-Daiya Road in Daiya } \\
\text { Forest Block }(\mathrm{C})\end{array}$ & - \\
\hline Acampe praemorsa & Vahi-hankal & $\begin{array}{l}\text { Near Katawali - Wali - Jer (A), Ambavi }(A) \\
\text { (Both the localities are present in Daiya Forest } \\
\text { Block in Panarwa Wildlife Range) }\end{array}$ & - \\
\hline
\end{tabular}

*Status is shown in parenthesis; A - abundant; C - common; R - rare. 